\title{
Design of an Innovative Business Model for Mobile Virtual Network Operators
}

DOI: 10.12776/QIP.V20I2.772

\author{
Miroslav Spaček, Emil Vacík
}

Received 21 August 2016, Revised 26 October, Accepted 12 November 2016

\begin{abstract}
Purpose: The article studies a possible innovative business model for sustainable competitive advantage in current communication technologies.

Methodology/Approach: This ethnographic approach consists of contextual interviews with company managers and specialists. Scientific observation and comparison took preference over other methods for the evaluation of results. Comparison methods were used for comparing price levels of telecommunication services within OECD countries and used for characterizing virtual operators. This method of modelling was applied to both corporate process-design and functions.
\end{abstract}

Findings: This paper proposes a normative model as the foundation for a virtual operator that would be generally applicable by any potential newcomer to the budding virtual telecommunication market.

Research Limitation: Business model innovation in the virtual mobile operator area is a quite new concept, which is still under development. For that reason the validation of the model has not been fully completed until now.

Originality/Value of paper: The paper demonstrates this quite new approach to business model development and its possible application in the area of virtual mobile operators.

Category: Conceptual paper

Keywords: virtual operator; telecommunications; business model innovation; sustainable innovation; structural modelling. 


\section{INTRODUCTION}

The establishment of a new business model in a newly developing business area such as mobile operator network services is always a great challenge both for newcomers and incumbents. Based on the commonly accepted idea that functional business models are valued above technical perfection of the product, newcomers using a well-established business model can often outplay incumbents.

The quickly developing branch of mobile operator services has undergone radical changes over past ten years. The mobile virtual operator establishment implemented some quite new business models, ambushing the existing oligopoly structure of operators while offering quite cheap and flexible services. This so called "disruptive innovation" represents a process whereby a smaller company with fewer resources may successfully challenge established incumbent businesses (Christensen, Raynor and McDonald, 2015).

The establishment and implementation of a new business model in order to be feasible and functional should be subject to certain formalised principles to avoid either misconceptions or failures. These "normative models" usually combine theoretical principles with empirical findings to arrive at a structured process for implementing the process in question. 'Business models' explain who your customers are and how you plan to make money by providing them with value; strategy identifies how you will beat competitors by being different' (Abraham, 2013).

Business model innovation usually represents fundamentally different method of making money compared to any previously well established and perceived processes. Business model innovation is viewed as a powerful way to transform existing markets or create entirely new ones (Giesen, et al., 2007). The new business model as a breakthrough innovation concept has already been addressed by various authors (Davila, Epstein and Shelton, 2006; Tidd, Bessant and Pavitt, 2007) and is considered an important source of competitive advantage and business performance.

Information and communication technologies (ICTs) offer unprecedented opportunities to rearrange value creation activities in new and different ways. In order to go deeper into this principle, the authors of this article examined new business model functions in the information technology business branch. Opting for this business area was driven by the fact that it has become almost the daily assignment for management to undergo rapid development and simultaneously look for new competitive advantages.

Over the course of time telecommunication companies have nearly exhausted new technology possibilities and all operate on equal technological standards. For instance, all three telecommunication operators in the Czech Republic ${ }^{1}$ offer

\footnotetext{
${ }^{1} \mathrm{O} 2$, T-Mobile and Vodafone
} 
the same technological platform and quite equal levels of technical support to customers. Moreover, their pricing policies, notwithstanding intrigue and hardly understandable tariff bundles, also lost their magic to attract customers. One possible way to find a way out of this problem is to embark upon a new business model, which might help all parties concerned - the current operator, new (virtual) operator and end-users. Such an idea, when transformed into a full operating model should result in a win-win-win situation, where all three parties involved in a new business can score success.

Searching for well-designed and functional business model in the mobile operator branch showed that such a normative model had not yet been developed. We hope to close this gap with our study. The normative model describing the key procedural steps for the establishment of virtual mobile operator represents the main benefit of this paper.

These conclusions are supported by the recent development of the market share of virtual mobile operators in the Czech Republic as shown the Table 1.

Table 1 - Market share development of virtual mobile operators in the Czech Republic

\begin{tabular}{|l|l|l|l|l|l|}
\hline Year & 2011 & 2012 & 2013 & 2014 & 2015 \\
\hline Market share (\%) & 0 & 0.06 & 1.15 & 6.53 & 6.81 \\
\hline
\end{tabular}

Source: ČTÚ (2016)

\section{THEORETICAL FRAMEWORK}

Despite lacking a commonly accepted definition of the concept (Zott, Amit and Massa, 2011), business models can be understood as a firm's comprehensive 'design or architecture of the value creation, delivery and capture mechanism' (Teece, 2010). Their main objective is to serve a company by commercialising its ideas and innovations. Business models comprise all elements relevant to the value offering provided to the firm's target customers, including internal and external value creation as well as its underlying resources and capabilities, along with the revenue generation logic applied by the firm. The logic of customer value resides at the core of business models. Value creation results either from the efficient provision of existing or generating new value propositions (Zott, Amit and Massa, 2010).

Amit and Zott (2012) define the business innovation model by three primary elements: (1) content - the activity to be performed, (2) structure - how and in what sequence activities are linked, (3) governance - which performs the activities. Osterwalder and Pigneur (2010) declare the roots of the business model as the rationale for how an organization creates, delivers and captures value. Keeley, et al. (2013) characterises business model innovation by the number of attributes of a business that are changed. 
Sustainability is one of set values that are increasingly a driver and target of business model innovation. Sustainability of business model innovation repeatedly explores the innovative business models that support sustainable technologies (Goebble, 2014). Such business model innovation is a method for firms to re-conceptualise the purpose of the firm and its value-creation logic to improve both its environmental and social sustainability (Bocken, et al., 2014).

Business model innovation is recognized as a key to the creation of sustainable business (Carayannis, Sindakis and Walter, 2015). Business model innovations for sustainability are innovations that create significant positives or significantly reduce negative impacts for the environment and/or society, through changes in the way the organisation and its value-network create, deliver and capture value or change their value proposition (Bocken, et al., 2014). Bocken, et al. (2014) introduced a more comprehensive view of how firms should approach embedding sustainability in their business models, by introducing sustainable business models innovation archetypes. These are introduced to develop a common language that can be used to accelerate the development of sustainable business models in research and practice (Laukkanen and Patala, 2014).

Business innovation models are conventionally focused on the firm's internal strategic activities, but these activities are greatly affected by the institutional environment in which the firms operate (Zott and Amit, 2007). They describe the rationale of how organisations create, deliver, and capture value (Osterwalder and Pignneur, 2010).

Changing markets and environmental forces have caused established firms to constantly rethink their existing business models, providing a new source of competitive advantage. A business model is described as a system of independent activities and it manifests in the causal relationship between choices and consequences (Casadesus-Masanell and Ricart, 2010). In one case an innovative business model occurs when a business model is invented in response to a demand and is then successfully implemented in practice. In a second case the new business model is required by the market. In both cases it is unclear at the beginning whether the business model will be useful as a market solution, or which business model will respond best to the demands of the market (Chesbrough and Rosenbloom, 2002).

An innovative business model can be a principal-based innovation or gradual with marginal changes (Bourreau, Gensollen and Moreau, 2012). Every company must design its own business model according to specific individual circumstances. Business model innovation as a new form of innovation plays a major role in sustainable company success, and is a tool for transformation and renewal (Demil and Lecocq, 2010). Competitive advantage must be built on strategic assets, such as a unique product, differential power in the channel, a speed to market advantage or some form of informational advantage. While business model innovation may require new capabilities, these new capabilities will constitute business innovation only when they significantly disrupt the competitive dynamics of an industry (Euchner and Ganguly, 2014). 
Opportunity exploration is commonly characterised as a multi-step process, involving various levels that lead from a broad idea to a feasible solution (Dimov, 2007). Opportunities involve the potential to generate some type of profit and involve certain kinds of improvement, innovation or imitation to compensate existing market inefficiencies (Singh, 2001). Being prepared in terms of constantly scanning the environment, connecting pieces of information, and evaluating the derived information are considered dimensions of individual's alertness (Tang, Kacmar and Busenitz, 2012).

Teece (2010) or Baden-Fuller and Mangematin (2013) interpret business models as 'sets of cognitive configurations that can be manipulated in the minds of managers'. Business model innovation requires strategic agility and entrepreneurial actions on the part of decision-makers (Sosna, TrevinyoRodriguez and Velamuri, 2010). A major managerial challenge is to counteract or at least alleviate the inhibiting impact of established dominant business logic and historically grown path-dependency in innovation decisions into new value proposition opportunities (Sydow, Schreyögg and Koch, 2009). Cognitive ambidexterity, e.g. the combination of analytic logic and affectively charged intuitive pattern recognition in strategic decision processes of leadership managers, fosters firm-level entrepreneurial behaviour ( $\mathrm{O}^{\prime}$ Reilly and Tushman, 2013).

Changes in social technologies can be considered an integral part of business model innovation, defined as adding new activities or changing existing activities in the operations of a business. Therefore, sustainable business model innovation involves the development of new social technologies that advance the sustainability of a firm. Business model innovation allows managers to resolve the apparent trade-off between innovation costs and benefits by addressing how they do business, for example, by involving partners in new value-creating activity systems (Amit and Zott, 2012).

Innovation systems can be considered the broader institutional structures that support technological innovation, including elements such as universities, governmental funding programs and regulations (Nelson and Nelson, 2002). Regulations shouldn't be formed around short-term political interests, but on long-term societal trajectories for sustainable innovations, which could also support a diverse set of alternate sustainable innovations, increasing sustainable development from the broader view. Business activities further need to collaborate with their stakeholders on sustainability issues, and also with each other to form common norms that support sustainable business model innovation.

Even under conditions of resource scarcity, organizations do not need to renounce innovation as a way of enhancing their performance prospects (Amit and Zott, 2012). An innovative business model can either create a new market or allow a company to create and exploit new opportunities in existing markets. Dell, for example, implemented a customer-driven, build-to-stock model of selling computers through retail stores (Brynjolfsson and Hitt, 2004). 
The innovation of business models in established firms can be categorised as a strategic investment of firm resources for future value creation, and the cognitive lens offers the potential to unravel respective processes of managerial thinking which lead to this kind of decision making (Baden-Fuller and Mangematin, 2013). Business models tend to be complex, as they represent boundary-spanning entities which link dimensions of corporate strategy, technological capabilities and innovation processes of the firm (Casadesus-Masanell and Ricart, 2010).

Business model innovation is characterised as an ongoing learning process that relies on discovery and trial-and-error (Smith, Binns and Tushman, 2010). Firms attempting to pursue business model innovations must overcome barriers such as obstruction and confusion among employees (Chesbrough, 2010). Of course, every company must assimilate these models in its own way, to accommodate its own internal culture and external environment (Euchner and Ganguly, 2014). Doing so successfully requires executives to overcome entrenched perspectives and cognitive biases, and it will almost certainly require changing the organizational culture to some extent (Evans and Johnson, 2013).

Slywotzky (2002) outlines 23 distinct business models, including the experience curve, cost leadership, multicomponent profit, and the dynamics that make them work. Business Model Canvas (Osterwalder and Pignneur, 2010), which is based on generation by brainstorming, is often criticised due to missing coherence or the relationship among elements (Euchner and Ganguly, 2014). It consists of nine building blocks: (1) customer segments, (2) value propositions, (3) channels, (4) customer relationships, (5) revenue streams, (6) key resources, (7) key activities, (8) key partnerships, and (9) cost structure. The Business Model Canvas approach can be used to carry out a full SWOT analysis of a company. It can be even used to seek out 'blue oceans', which are new value propositions that aren't embattled by rivalries (Abraham, 2013).

Business innovation modelling represents a conscious renewal of firm's core business logic. Teece (2010) emphasises that the reliability of the business model architecture to generate and capture value depends on a deep and comprehensive understanding of customer needs. A company's business model must be changed if its ability to create, deliver, or capture value declines (Kaplan, 2012).

The business model doesn't work, if an organization has completed a considerable strategic or organisational change (reengineering, acquisition etc.) For those types of things, strategies and strategic analysis are needed (Abraham, 2013).

\section{RESEARCH QUESTIONS AND METHODOLOGY USED}

Our research is based on a comprehensive literature review (Boote and Beile, 2005 ) in the areas of system theory and business model innovation research. By the use of existing contemporary literature reviews we attempted to analyse system approaches that can be best applied to business model innovation drafts. 
Because there is not a commonly shared understanding of business model innovation content in the resources reviewed, it was necessary to carry out a critical analysis of the outputs and confront their applicability for the specific purposes of this research.

Research questions raised in the context of this paper are in consonance with the gap earlier disclosed in this paper. Over the past years the business model has been developed by telecommunications companies, but its implementation phase was not addressed at all: (1) is such a business model feasible in this environment? (2) What are the requirements for partial procedural steps of the business model? (3) Are formulated procedural steps valid and relevant for both parties concerned (mobile operators and virtual mobile operators)?

Ethnographic research became due to the need of doing contextual interviews convenient methodological tool (Dey, 2002). Contextual interviews were applied to the group of company managers and specialists who were actively involved in the design of a new business model. As methods used for the evaluation of results, scientific observation and comparison took preference over others. The comparison method was used for comparing price levels of telecommunication services within OECD countries while the explanation was used for the characterization of virtual operators. This method of modelling was applied to corporate process design and functions.

The practical aspects of the research were explored in the rapidly changing telecommunication business, which after years of decent oligopoly competition faces upcoming distribution of new frequencies as well as entering new virtual operators.

\section{SPECIFICATION OF A VIRTUAL OPERATOR}

The fundamental difference that distinguishes standard and virtual operators is their access to infrastructure. A virtual operator operates as a provider of telecommunication services to end users without either the possession of full infrastructure or the licence for using radio frequencies.

Such an operator usually declares its corporate identity through its own brand. A virtual operator is marked by the abbreviation MVNO (Mobile Virtual Network Operator). Due to existence of various types of virtual operators, their definition is often excessively general. As an example, the British telecommunication market regulator defines a virtual operator as 'The organization which offers telecommunication services to customers without possession of broadcasting time' (Ofcom, 2004, p. 17). According to the International Telecommunication Union (ITU) definition: 'Mobile virtual operator is an operator which offers telecommunication services, but it doesn't licence for radio frequencies. Usually it assigned an identification number, by which it logs in into network and in 
many cases it issue as SIM card (ITU, 2011)'. The first Czech virtual operator BLESKmobile further extended the definition of ITU by factors of marketing, distribution and customer support (RAS, 2012, p. 5).

\subsection{Virtual operator models}

The term MVNO (Mobile Virtual Network Operator) is ambiguous. It contains more attitudes to functions, strategy and technical solution. The main models of MVNO are characterized as branded reseller, service operator and full MVNO, which are mostly contractually bound to a traditional network operator MNO (Mobile Network Operator). Typically three possible models of mutual relationships among MNO, MVNE and MVNO are described (Špaček and Štěpán, 2013). In the traditional model, is the only provider MNO. In the MVNO model, is the infrastructure hired and services are offered to customers under its own brand. MVNE (Mobile Virtual Network Enabler), hires technical solutions, which are afterwards leased to MVNO. The general trend seems to be an evolution towards an MVNO with ownership of the entire core network architecture and where MNO is buying access to it (Balon and Liau, 2012).

\subsection{Virtual operator value chain}

Fig. 1 describes in detail the value chain of individual types of virtual operators. This value chain breaks down provider operations into individual processes. From the point of view of strategy, one must clearly define the processes that are sources of competitive edge. The only viable model of virtual operator is that which brings competitive advantage and is able to successfully compete on a telecommunication market which is becoming more competitive than ever.

The MVNO (Mobile Virtual Network Operator) potential to reach success was tested against a business environment structure (Shin, 2008) and revealed that the business environment structure can significantly influence the position of MNVO. In case that MNO (Mobile Network Operator) is vertically integrated, this operator is then able to charge monopoly prices and thus the ability of MNVO to offer services is constrained.

From this point of view a horizontally layered structure seems to be more inviting for MVNO. For this reason, MVNOs which operate in West European markets are far more successful to be compared with competitors acting in Asia. Applied pricing policy is to a large extent influenced by both the level of oligopoly strength of the MNO (Le Cadre and Bouhtou, 2012) and the behaviour of other MVNOs (Zhao, Zhu and Zhu, 2012). 


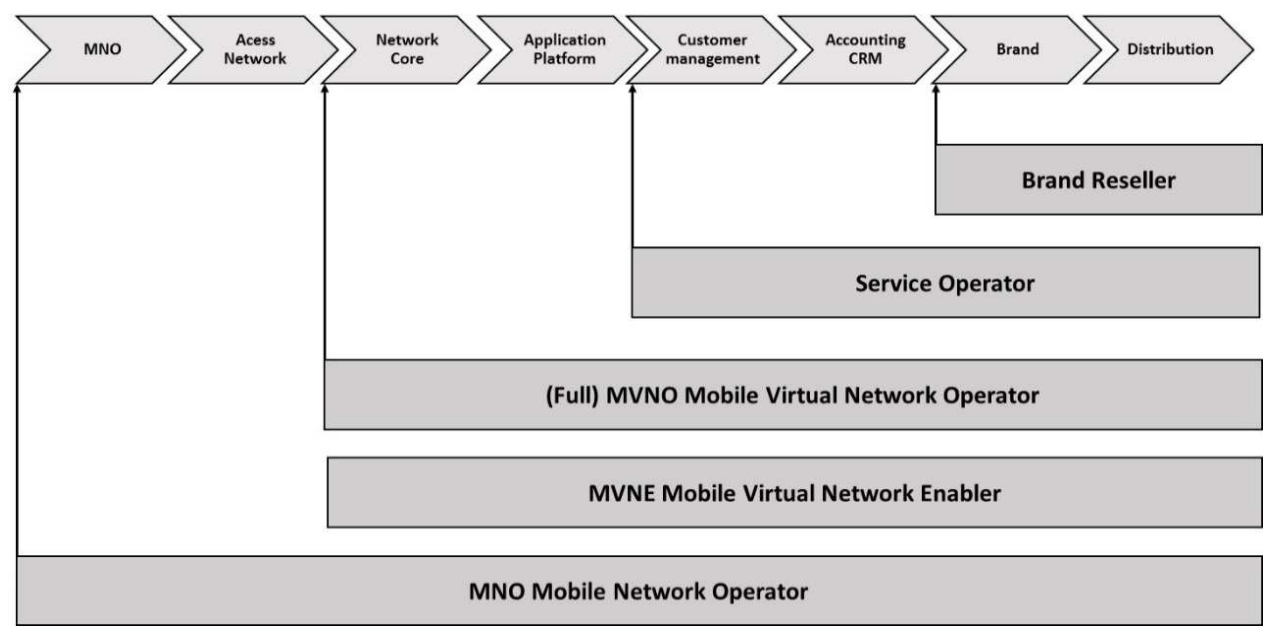

Adapted according: NSN (2004, p. 4)

\section{Figure 1 - Types of mobile operators}

A Brand reseller aims to provide customers with services and building their own brand. A branded reseller doesn't own any infrastructure; it hires a comprehensive technical solution from either an MNO or other virtual operator. Branded resellers manage the image of their own brand and distribution channels as well. Notwithstanding a brand reseller's direct contact to end users, all data on customers and accounting administration is arranged for by their business partner.

Such a partner is directly bound by contract to the brand reseller's customers. The brand reseller's profit margin is derived from the difference between the wholesale price of a one minute call, which is paid to the host MNO, and the retail price which is settled by the end user. The nature of saving costs for the brand reseller is accomplished by using the same distribution network as the parent company.

BLESKmobil uses identical distribution channels such as newspaper stands both for pre-paid cards and the Blesk tabloid. Since a brand reseller need not build either its own network or infrastructure, this business model is least demanding for capital expenditure. A brand reseller can approach even a small segment of end users that are then consolidated into clusters with certain specific characteristics such as operating on the same premises or having similar or very similar needs. As an example, he may set an offer of special tariffs for students. Brand resellers are only restrained in capability to innovate their own services to those provided by the infrastructure operator. The space for price adjustment is limited (Špaček and Štěpán, 2013).

The service operator ranks between the brand reseller and full MVNO. This model offers more flexibility than the brand reseller model, especially in terms of managing customer relationships, pricing strategy, and amount and structure of 
the services offered. Service operator models are, from a technical point of view, more complicated, because service operators operate their own IT system. Compatibility of both IT systems is an underlying factor for optimum collaboration with a MNO.

Due to the interconnection of both IT systems there is an increased dependence by a service operator on its host MNO. The service operator model enables price competition with the host $\mathrm{MNO}$ since the service operator is allowed to actively manage customer relationships (CRM) as well as influence price strategy. In this way a competition between the virtual and host operator may come into effect, especially in segments with high profit margins (premium segment).

The MNO often regards service operators as competitors and is sometimes not willing to lease infrastructure to them. A possible solution to this problem is either signing an agreement, where the host reserves conditions which are favourable to him or taking only market positions that create synergic effects.

The full MVNO (Mobile Virtual Network Operator) includes ownership and operation of the complete infrastructure except its Business Support system (BSS). A full MVNO issues its own SIM card with unique IMSI identification and a specific phone number with its own dialling code. Call termination fees ${ }^{2}$ are charged as a liability of the full MVNO. The full MVNO hires the base stations system only.

As opposed to previous types of virtual operators, the advantages of full MVNO consist in the interconnection of calls, better flexibility with respect to the MNO and innovation opportunities. A full MVNO, as distinguished from service operators and brand resellers, is relatively independent of the host. If the full MVNO decides to change the host MNO, there is neither a need to change end user SIM cards nor to change the settings of the IT solution. A full MVNO can also offer all the services a MNO does. The only limiting element is the quality of the host MNO network (2G, 3G or 4G system). When a higher quality BSS is desired then it becomes necessary to change the host. In general, the larger part of its own infrastructure the operator controls the higher possibilities for virtual operators to exist (Špaček and Štěpán, 2013).

The MVNE (Mobile Virtual Network Enabler) model differs significantly from the aforementioned models. This type of virtual operator has no direct contact with the end user. Its core business resides in services mediation to other virtual operators. As a matter of practice, MVNE uses the system of base stations (BTS and BSC systems) of the MNO operator. Additional systems like NSS (Network System Security) and OSS (operational support system) are in possession of MVNE. Applicants who want to operate MVNO can use the structure that MVNE already owns and leases. MVNE then arranges for client access to other networks, establishes a virtual switchboard and connects the call with that person to be called.

\footnotetext{
${ }^{2}$ It means rates which mobile operators charge to each other.
} 
A typical example of MVNE in the Czech Republic is the Telematika Company which collaborates with $\mathrm{O} 2$ and thus it achieves complete Czech Republic region coverage.

\subsection{Criteria of Mobile Virtual Network Operator (MNVO) choices}

First of all, one must choose an appropriate type of MVNO. This represents a complex multi-criteria decision making process. When choosing a proper set of criteria it is inevitable to observe all those aspects that contribute to competitive advantage as well as those that represent key risk factors.

First of all, the time factor is worth mentioning, since current market demand for cheaper operators will be continuously compensated for an increasing number of new virtual operators entering the telecommunication market. Another risk factor that may hamper successful MVNO establishment is initial investment costs. Providing that the project didn't work out, it would be difficult to sell partially worn out technical equipment.

But ownership results in the increase of profit margins, which accounts for another possibility. As a matter of fact, the establishment of MVNO would always be backed by a feasible legislative process which may vary by the model chosen. At the end, a company needs effective process management to be purposefully established. The number of employees, organizational structure and other aspects of company management are crucial to company success. The skills of company management should thus be considered as a criterion.

\section{PROPOSAL OF A NORMATIVE BUSINESS MODEL INNOVATION AIMED AT ESTABLISHING A VIRTUAL OPERATOR $^{3}$}

Even if the approach to establishing a virtual operator may differ slightly from case to case, it is possible to generalize findings from the current practice of existing and potential virtual operators. Thus a set of recommendable steps for a normative business model innovation draft can be made to establish a competitive virtual operator. This model has been further refined. The setting up consists of the following steps.

\subsection{Macro and microeconomic analysis}

The analysis performed by the authors proved the priority of information, which is necessary for managerial decision about further development of the virtual operator establishment project. Ascertained opportunities and threats are the risk

\footnotetext{
${ }^{3}$ The chapter comes out of the normative model addressed by Špaček and Štěpán (2013) which was broadened, refined and tested in the sense of research questions set forth in this text.
} 
factors which are analysed whether an environment is suitable for the establishment of a virtual operator.

\subsection{Internal company analysis}

Analysis of internal company's environment confirms strengths and weaknesses, that determine the unique assets or competences a company has and whether it is possible to offer them to a Mobile Network Operator (MNO) in partnership. Such an approach identifies potential synergic effects from which both companies will benefit. The outcome of this analysis is always a set of tangible or intangible assets which may be the source of competitive advantage.

\subsection{Strategic goals determination}

Strategic goals are determined in agreement with the well-known SMARTER principle (Fotr, et al., 2012). Long-term strategic goals at the corporate level should be reduced to partial goals tied to individual processes. For the effective implementation a set of short-term goals must be derived from long-term goals. The implementation process can be supported by special methodology, such as Balanced Scorecard.

\subsection{Process organizational structure determination}

The main goal of the process organizational structure determination is to find such process architecture, where each process contributes to company value creation. Key company processes are marketing, new customer recruitment, service delivery and customer support. Each of these processes is assigned a process 'owner' responsible for complete management including goal settings, incorporation of permanent improvement principles and sources allocation. The outcome is a proposal of company process structure to be visualized by a company process map.

\subsection{Elaboration of a marketing plan}

The important aspect of a marketing plan is market segmentation. It is evident that a Mobile Virtual Network Operator (MVNO) most effectively operates when customers are satisfied within particular segments. Research done in the Czech Republic ascertained that there are dissatisfied customer segments in the Czech telecommunication market (Špaček and Štěpán, 2013). The marketing plan is based on the '4P principle' (product, price, placement, promotion). That is extended by an additional ' $3 \mathrm{P}$ ' in the service sector (people, processes, physical evidence). $4 \mathrm{P}$ is then collated with $4 \mathrm{C}$ one (customer value, customer costs, communication, convenience) so that the customers' standpoint is properly reflected. 


\subsection{Choice of Mobile Virtual Network Operator (MVNO) type according to criteria}

The process of choosing an MVNO type is subject to meeting already specified criteria, the objective being to find a model that best fits predefined criteria. The set of predefined criteria posted in this paper arose from the research and mirrors the most important operator preferences. They may still adapt to fit a particular situation. Criteria evaluation process adheres to the commonplace principles of managerial decision making (Fotr, 2006).

\subsection{Corporate strategy elaboration}

Investors shall make investment decisions that confirm the economic effectiveness of the project as well as financial decisions based on the financial viability of the project. This means an investor must be assured that for each year of the project he will receive such a combination. The point which must remain in focus is human resources management.

The corporate strategy reflects customer preferences, market and segment situation and competitors activities. Based on key company competences the strategy have to preserve flexibility simultaneously with focus on low cost competitiveness.

\subsection{Critical success factors (CSF) determination}

While discussing virtual operator expertise, the following four critical success factors were determined: (1) negotiation with Mobile Network Operator (MNO) and coming to terms, (2) reliable function of a network, (3) web application quality, and (4) cost overruns, shortage of cash flow.

\section{Negotiation with MNO}

Suggestive and persuasive presentation of the proposal to the MNO is a keystone of project success. Composition of a team to be in charge of negotiation must be both representative (CEO and Corporate Heads) and professionally highly qualified (telecommunication experts). The project must be clearly defined and its layout must be at highly illustrative and understandable. The synergic effects and benefits for both parties must be effectively highlighted. The concept must properly address the type of Mobile Virtual Network Operator (MVNO), as well as outcomes of previous analyses, technical solutions to the project, tangible and intangible assets to be invested, securing financial sources, proving economic effectiveness and commercial viability supported by guarantees to investors. Remember thorough risk analysis and the set of provisions for their mitigation.

On the other side the MNO must indicate if the proposal is worth further discussion. Both parties should play win-win game. If the project seems profitable for both parties it is inevitable to proceed with negotiation on further agreement. It is tedious work and both party lawyers must play their roles. 


\section{Notification to Czech Telecommunication}

Depending on the model chosen some obligations to the MNO may occur. The scope and nature of these obligations should be properly addressed in PESTEL analysis. This basically deals with the compliance with the Law No. 127/2005, which sets up conditions for communication activities execution. This legal norm is applicable to all sorts of networks and electronic communication services.

\section{DISCUSSION AND FINDINGS}

Business model innovation is considered one of the vehicles that drive prosperity. Operating a functional Business model is widely understood to be superior to having a good and technically perfect product. Considering the establishment of a new business model is relevant in situations where obsolete business models no longer reflect customer needs.

Such a situation came into existence over the past several years where the oligopoly telecommunication market was unable to satisfy customer needs in terms of providing high quality service at affordable prices. For this reason Czech government enabled a relaxation of the Czech telecommunication market to enable so called 'virtual operators' to enter the Czech telecommunication market.

Mobile Virtual Network Operator offers a new business model that brings added value to both providers and end-users. This business model is spreading across the world and includes more approaches to operation, strategy and technical solution. The launch of virtual operators is supposed to come into existence in the Czech Republic in near future.

Even the first 'early bird' BLESKmobil has already noticed. The virtual operator business model brings new benefits like lower demands for capital expenditure. Prior to formulation of a normative model, thorough analyses of macro and micro environments were performed so that the suitability of the Czech telecommunication market for a new virtual operator establishment would be properly judged. As measured by the Herfindahl-Hirschman Index (HHI) it was found that Czech telecommunication market had an oligopoly character. The three existing rivals don't exert sufficient competitive pressure which would level prices to the European market.

The normative model presented in this paper was built up step by step based on fundamental information from internal and external environment. Then process organizational structure was defined, goals were determined, marketing plan was formulated. After that it was posible to set criteria for the Mobile Virtual Network Operator (MVNO) type negotiation. Finally corporate strategy was confirmed and critical success factors were set.

The key finding was that, notwithstanding reinforcing competitive pressure caused by newcomers, the Czech telecommunication market is still very 
promising and profitable for newcomers (see Tab. 1). The paper sought answers to three research questions. The answers follow: (1) the presented business model is feasible in the environment of the virtual mobile operator. This finding was approved by the managers and specialists of the virtual mobile operator BLESKmobile after having tested the model on selected data. (2) Partial procedural steps of the model were presented in the paper (see Chapter 5).

The requirements for the procedural steps were derived from both the literature reviews and contextual interview with virtual mobile operator managers and specialists. These requirements include corporate strategy, macro and micro environment analysis, thorough internal company analysis including core competences, resources review and company intangible assessment such as human capital, organization and information base. Specific regulatory requirements must be taken into account as well.

Based on this requirement the critical success factors of the implementation of mobile virtual operator were determined (see Chapter 5.8). (3) Formulated procedural steps are valid because data exists for each proposed procedure. The model is complex and flexible because it is possible to make corrections in real time upon the finding of fundamental changes in the environment. It reflects the actual strategy of mobile operators and that's why it can be taken as relevant for the establishment for the new virtual mobile operators.

\section{CONCLUSION}

The paper deals with the determination of business innovation model possibilities by creating sustainable competitive advantage in the branch of contemporary information and communication technologies. The business model innovation design is always closely connected with the business strategy of the firm.

Some authors like Porter are convinced that firm's strategy is on a higher level than business model innovation and it represents the only way to achieve superior profitability of the firm. As to be directed into future, both strategy and business model innovation must mitigate a number of risks. But on the other side, risk factors may also present an opportunity for starting new businesses and safeguarding them by competitive advantage. From this point of view firm's strategy and business innovation model must be in consonance.

The success rate of created business model innovation can be multiplied by rationally set regulation criteria, which in the long-term leads to sustainability of the system. The business model innovation is specific for each branch and company and underlies actual changes in the environment.

This paper presents the structured normative model of virtual operator foundation which hasn't yet been solved and would be almost generally applicable by any potential newcomer to the budding virtual telecommunication market. The research verified feasibility of this model that responds to the demand of virtual telecommunication operators. The normative model was primarily designed on a 
theoretical base that was confirmed by the opinions of virtual mobile operator managers and specialists. Further validation of this model in practice is the future challenge for the applied research.

\section{ACKNOWLEDGMENTS}

This paper was elaborated with the subsidy of IGA2 304015 at University of Economics in Prague.

\section{REFERENCES}

Abraham, S., 2013. Will business model innovation replace strategic analysis? Strategy and Leadership, 41(2), pp.31-38.

Amit, R. and Zott, C., 2012. Creating value through business model innovation. MIT Sloan Management Review, 53(3), pp.40-49.

Baden-Fuller, C., Mangematin, V., 2013. Business models: A challenging agenda. Strategic Organization, 11(4), pp.418-427.

Balon, M. and Liau, B., 2012. Mobile Virtual Network Operator Architecture Evolution and Economic Stakes. In: Proceedings from the 15th International Telecommunications network Strategy Symposium (NETWORKS), Rome, Italy, October, pp. 15-18.

Bocken, N.M.P., Short, S.W., Rana, P. and Evans, S., 2014. A literature and practice review to develop sustainable business model archetypes. Journal of Cleaner Production, 65, pp.42-56.

Boote, D.N. and Beile, P., 2005. Scholars before Researchers: On the Centrality of the Dissertation Literature Review in Research Preparation. Educational Researcher, 34(6), pp. 3-15.

Bourreau, M., Gensollen, M. and Moreau, F., 2012. The impact of a radical innovation on business models: Incremental adjustments or big bang? Industry and Innovation, 19(5), pp.415-435.

Brynjolfsson, E. and Hitt, L., 2004. Intangible Assets and the Economic Impact of Computers. In:, W. Dutton, B. Kahin, R. O’Callaghan and A.W. Wyckoff eds. Transforming Enterprise. Cambridge, Massachusetts: MIT Pres, pp.27-48.

Carayannis, E.G., Sindakis, S. and Walter, C., 2015. Business Model Innovation as Lever of Organizational Sustainability. The Journal of Technology Transfer, 40(1), pp.85-104.

Casadesus-Masanell, R. and Ricart, J.E., 2010. From strategy to business models and onto tactics. Long Range Planning, 43(2-3), pp.195-215. 
Český telekomunikační úřad (ČTÚ), 2016. Seznam poskytovatelů mobilních služeb. [online] Available at: http://www.apms.cz/pro-spotrebitele/seznamposkytovatelu-mobilnich-sluzeb.

Chesbrough, H., 2010. Business model innovation: Opportunities and barriers. Long Range Planning, 43(2-3), pp.354-363.

Chesbrough, H. and Rosenbloom, R.S., 2002. The role of the business model in capturing value from innovation evidence from Xerox Corporation. Industrial and corporate change, 11(3), pp.529-555.

Christensen, C., Raynor, M.E. and McDonald R., 2015. What is Disruptive Innovation? Harvard Business Review, December, pp.44-53.

Davila, T., Epstein, M.J. and Shelton, R., 2006. Making innovation work: how to manage it, measure it, and profit from it. Upper Saddle River: Wharton School Publishing, XXVI, ISBN 01-314-9786-3.

Demil, B. and Lecocq, X., 2010. Business model evolution. In search of dynamic consistency. Long range planning, 43(2-3), pp.227-246.

Dey, C., 2002. Methodological issues: The use of critical ethnography as an active research methodology. Accounting, Auditing \& Accountability Journal, 15(1), pp.106-121.

Dimov, D. P., 2007. Beyond the single-person, single insight attribution in understanding entrepreneurial opportunities. Entrepreneurship Theory and Practice, 31(5), pp.713-731.

Euchner, J. and Ganguly, A., 2014. Business model innovation in Practice. Research-Technology Management, 57(6), pp.33-39.

Evans, J. D. and Johnson, R. O., 2013. Tools for managing early-stage business model innovation. Research-Technology Management, 56(5), pp.52-56.

Fotr, J., Švecová, L., Dědina, J., Hrůzová, H. and Richter, J., 2006. Manažerské rozhodování [Managerial decision making]. Praha: Ekopress s.r.o, ISBN 8086929-15-9.

Fotr, J., Vacík, E., Souček, I., Špaček, M. and Hájek, S., 2012. Tvorba strategie a strategické plánování: teorie a praxe [Creating a strategy and Strategic Planning: Theory and Practice] 1st. Edition. Praha: Grada Publishing. ISBN 978-80-2473985-4.

Giesen, E. Berman, S., Bell, R. and Blitz, A., 2007. Three ways to successfully innovate your business model. Strategy and Leadership, 35(6), pp.27-33

Goebble, M.M., 2014. Business Model Innovation. Research-Technology Management, 57(6), pp.58-60.

International Telecommunication Union (ITU), 2011. Regulatory Treatment of Mobile VNOs. April 4. [online] Available at: http://www.itu.int/osg/spu/ni/3G/resources/MVNO/index.html 
Kaplan, S., 2012. The Business Model Innovation Factory: How to Stay Relevant When the World is Changing. John Wiley \& Sons.

Keeley, L., Pikkel, R., Quinn, B. and Walters, H., 2013. Ten types of Innovation: The Discipline of Building Breakthroughs. Hoboken, NJ: John Wiley \& Sons.

Laukkanen, M. and Patala, S., 2014. Analysing barriers to sustainable business model innovations: Innovation system approach. In: XXV ISPIM Conference Innovation for Sustainable Economy \& Society, Dublin, Ireland. Retrieved from Www.ispim.org.

Le Cadre, H. and Bouhtou, M., 2012. Modelling MNO and MVNO's dynamic interconnection relation: is cooperative content investment profitable for both providers? Telecommunication Systems, 51(2-3), pp. 193-217.

Nelson, R. R. and Nelson, K., 2002. Technology, institutions, and innovation systems. Research Policy, 31(2), pp. 265-272.

Nokia Siemens Networks (NSN). Mobile Virtual Network Operator, 2004.

[online] Available at: http://www.mvnodynamics.com/wpcontent/uploads/2011/05/MVNO_A4_2106.pdf

Ofcom, 2004. The Communications Market. Telecommunications, October. [online] Available at: www.ofcom.org.uk/research/cm/cmpdf/telecoms.pdf.

O’Reilly, C.A. and Tushman, M.L., 2013. Organizational ambidexterity: Past, present, and future. Academy of Management Perspectives, 27(4), pp.324-338.

Osterwalder, A. and Pignneur, Y., 2010. Business Model Generation. A Handbook for Visionaries, Game Changers, and Challengers. New Jersey: John Wiley \& Sons.

Ringier Axel Springer (RAS), 2012. Presentation of the project BLESKmobil. [online] Available at:

http://www.ringieraxelspringer.cz/system/files/article/2012/10/cs1274.pdf?downl oad $=1$.

Shin, D.,H., 2008. Overlay networks in the West and the East: a technoeconomic analysis of mobile virtual network operators. Telecommunication Systems, 37(4), pp.157-168.

Slywotzky, A., 2002. The Art of Profitability. New York: Warner Books.

Smith, W.K., Binns, A. and Tushman, M.L., 2010. Complex business models: Managing strategic paradoxes simultaneously. Long Range Planning, 443(2-3), pp.448-461.

Sosna, M., Trevinyo-Rodriguez, R.N. and Velamuri, S.R., 2010. Business model innovation through trial-and-error learning: The Naturhouse Case. Long Range Planning, 43(2-3), pp.383-407.

Singh, R., 2001. A comment on developing the field of entrepreneurship through the study of opportunity recognition and exploitation. Academy of Management Review, 26(1), pp.10-12. 
Sydow, J., Schreyögg, G. and Koch, J., 2009. Organizational path dependence: Opening the black box. Academy of Management Review, 34(4), pp.689-709.

Špaček, M. and Štěpán, M., 2013. Designing New Business Model As A Breakthrough Innovation For Competitive Advantage Creation. In: Proceedings International Days of Statistics and Economics (MSED). [CD-ROM]. VŠE, September, 2013, pp.1400-1410. [online] Available at: https://msed.vse.cz/files/2013/18-Spacek-Miroslav-paper.pdf

Tang, J., Kacmar, K.M. and Busenitz, L., 2012. Entrepreneurial alertness in the pursuit of new opportunities. Journal of Business Venturing, 27(1), pp.77-94.

Teece, D. J., 2010. Business models business strategy and innovation. Long Range Planning, 43 (2-3), pp.172-194.

Tidd, J., Bessant, J. and Pavitt, K., 2007. Řízení inovací: zavádění technologických, tržních a organizačních změn [Innovation management: the introduction of technological, market and organizational changes]. 1st. edition, Brno: Computer Press. ISBN 978-80-251-1466-7.

Zhao, S., Zhu, Q. and Zhu, H., 2012. Optimal Price Strategy Selection for MVNO in Spectrum sparing: An Evolutionary Game Approach. KSII Transactions on Internet and Information Systems, 6(12), pp.3133-3151.

Zott, C. and Amit, R., 2007. Business model design and the performance of entrepreneurial firms. Organization Science, 18(2), pp. 181-199.

Zott, C., Amit, R. and Massa, L., 2010. Business model design: an activity system perspective. Long range planning, 43(2-3), pp.216-226.

Zott, C., Amit, R. and Massa, L., 2011. The business model: Recent developments and future research. Journal of Management, 37(4), pp.1019-1042. 


\section{ABOUT THE AUTHORS}

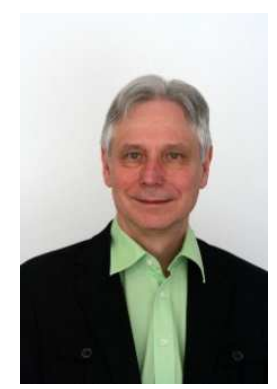

Doc. Ing. Miroslav Špaček, Ph.D., MBA is an Associate Professor in the Department of Entrepreneurship, Faculty of Business Administration at the University of Economics in Prague, Czech Republic. His scientific work is oriented toward post-implementation appraisals of investment projects as well as on innovation management. In the past he held top managerial positions in both chemical and pharmaceutical companies. Tel. +420602477517, miroslav.spacek@vse.cz

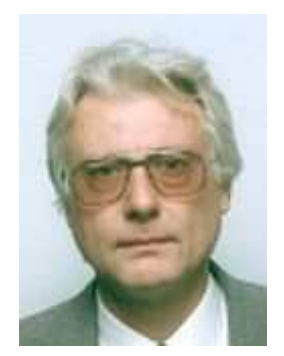

Doc. Ing. Emil Vacík, Ph.D. is an Associate professor in the Department of Strategy, Faculty of Business Administration at the University of Economics in Prague, Czech Republic His scientific work is oriented toward various aspects of company strategic planning, risk management and company performance measurement. In the past he held various top managerial positions in industrial companies. University of Economics, Prague, W. Churchill Square 4, 13067 Prague 3, Czech Republic, emil.vacik@vse.cz 